\title{
Histopathological effect of sub-lethal concentration of aluminum phosphide (phostoxin) on Clarias gariepinus juveniles ${ }^{1}$
}

\author{
Kayode B. Olurin ${ }^{2}$, Godwin O. Mbaka ${ }^{3 *}$ and Olubunmi A. Agbato ${ }^{2}$
}

\begin{abstract}
ABTSRACT.- Olurin K.B., Mbaka G.O. \& Agbato O.A. 2016. Histopathological effect of sublethal concentration of aluminum phosphide (phostoxin) on Clarias gariepinus juveniles. Pesquisa Veterinária Brasileira 36(7):574-580. Department of Anatomy, Lagos State University College of Medicine, Ikeja, Lagos, Nigeria. E-mail: mbaaka2gm@gmail.com

The study evaluated the effect of sub-lethal concentration of phostoxin on Clarias gariepinus juveniles. C. gariepinus juveniles belonging to the same cohort $(40.1 \pm 1.2 \mathrm{~g} ; 18.1 \pm 1.1 \mathrm{~cm})$ from a commercial fish farm were randomly placed ten in each of 15 plastic tanks containing 15 liters of water. They were exposed for $96 \mathrm{hrs}$ to three sub-lethal concentrations (treatments) of phostoxin $\left(0.125,0.250,0.5 \mathrm{mg} \mathrm{L}^{-1}\right)$ and a phostoxin free control. At the end of $96 \mathrm{hrs}$ exposure, they were dissected and the tissues need for histopathology removed and fixed in Bouin's fluid. The gill filament exhibited fusion at the secondary lamella that was progressive with concentration. At the highest concentration of exposure, the secondary lamellae showed marked pyknotic and necrotic changes characterized by epithelia detachment. The hepatic tissue showed mild inflammatory changes at lower concentrations while at the highest concentration of exposure there was marked inflammation with observed hydropic degeneration. In the kidney, an inflammatory change was only observed in the interstices at the highest dose of exposure with the convoluted tubules showing partial shrinkage. Phostoxin showed to have significantly caused alterations in cyto-architecture of the gills and to a considerable extent liver and kidney of $C$. gariepinus.
\end{abstract}

INDEX TERMS: Histopathology, phostoxin, toxicity, organs, Clarias gariepinus, juveniles.

\section{INTRODUCTION}

Fish are exposed to various contaminants or pollutants in the aquatic environment leading to decreased growth, alterations in physiological processes and ultimately death. These contaminants which are obtained from the aquatic environment and food cover a wide spectrum of gases, chemicals and solids. Most toxicological studies have been limited to the effects of lethal or acute doses of these pollutants (Martinez \& Souza 2002, Huertas et al. 2002, Das et al. 2004a), whereas, subtle physiological disorders result with exposure to sub-lethal/low doses of toxicants (Das et al. 2004b ,Varo et al. 2007, Kori-Siakpere et al. 2011). Various workers have reported histopathological changes in fish organs (e.g. liver, gills, kidney, lungs etc) exposed to sub-lethal concentrations of pollutants (Stentiford et al. 2003, Rabitto et al. 2005).

\footnotetext{
${ }^{1}$ Received on June 16, 2015.

Accepted for publication on April 16, 2016.

${ }^{2}$ Department of Plant Sciences and Applied Zoology, Olabisi Onabanjo University, Ago-Iwoye, Ogun State, Nigeria.

${ }^{3}$ Department of Anatomy, Lagos State University College of Medicine, Ikeja, Lagos, Nigeria. *Corresponding author: mbaaka2gm@gmail.com
}

The use of synthetic pesticides in grain storage is commonly practiced in the West Coast of Africa, particularly in Nigeria. This method of grains preservation by farmers has received strong encouragement from the government for the purpose of achieving food security (Atta et al. 2009). Unfortunately, most of these pesticides have shown to be of health risk to man and the environment (Ofuya et al. 2010). The like of Aluminium phosphide (phostoxin) commonly called "trebor" by local farmers in Nigeria is used for the eradication of weevils in stored grains especially in maize. In some cases, the tablets are mistakenly ground with the maize used as an ingredient in fish feeds and are fortuitously consumed by fish in their diets (Atta et al. 2009). Although aquatic life can tolerate some measure of stress and occasional adverse effects (Shuhaimi-Othman 2012), the quantity of aluminum phosphide in the aquatic food chain might be sufficient to cause changes in cyto-achitecture of the vital organs resulting to alteration in normal body function and growth.

Phostoxin which is either in form of tablets or pellets contains 55\% aluminum phosphide as its active ingredient and $45 \%$ inert which is used as the carrier of the active 
ingredient. When exposed to water reacts to liberate phosphine gas as shown in the equation below (Gordon 1972). Phosphine gas is by far the dominant means of controlling pest insects in stored grain and many other stored commodities (Nath et al. 2011). The phosphine gas emitted is the poison used to kill insect pests in grains without affecting grain viability (Atta et al. 2009). Because phosphine gas is highly toxic to aerobic organisms it could therefore be of considerable health risk to aquatic life. The phosphine gas is colorless and odorless in its pure form but, due to the presence of substituted phosphines and diphosphines, it has a foul odor resembling decaying fish (Chugh 1992). Phosphine is gaseous above $-88^{\circ} \mathrm{C}$ which allows it to disperse readily during fumigation. The concentrated phosphine is potentially explosive in air and can autoignite at near ambient temperatures. However, the commercial aluminium phosphide contains ammonium carbamate which liberates non-flammable and inert agents to reduce fire hazards (Nath et al. 2011):

$$
\mathrm{AlP}+3 \mathrm{H}_{2} \mathrm{O} \rightarrow \mathrm{Al}(\mathrm{OH})_{3}+\mathrm{PH}_{3}
$$

The mechanism of cytotoxicity of aluminum phosphide on aquatic life is not fully understood. However, in rainbow trout, the reported acute $\mathrm{LC}_{50}$ is $4.1 \mathrm{ug} / \mathrm{L}$, indicating very high toxicity (Leuschner 1984). Aluminum phosphide will rapidly react to form phosphine gas which is somewhat soluble in water. The noxious gas which is not known to be absorbed dermally have their main routes of exposure to the body systems through ingestion and inhalation and have shown to be highly toxic via both routes (Degesch 1988). The contact of the gas with the gills readily affects the secondary lamellar, a tender projection from the primary lamellar having delicate epithelial lining for easy gaseous exchange. As reported (Ayoola \& Ajani 2007), the effect of the gas on the delicate cellular membrane result to mucus accumulation that cause hypoxia which could lead to death. On the other hand, the ingested phosphine gas is rapidly absorbed throughout the gastrointestinal tract, leading to systemic toxic effects. The action is modulated through an increase in superoxide dismutase activity and decrease in catalase levels which result in increased formation of free radicals and accelerated lipid peroxidation (Wahab et al. 2008). The increase in lipid peroxidation is known to cause membrane damage and then a change in cellular ionic balance leading to cells death (Wahab et al. 2008).

Clarias gariepinus is a North Africa catfish that live in a variety of fresh water environment including quiet waters, lakes and pools and prefer rather shallow and swampy areas with a soft muddy substrate and calmer water. They may also occur in fast flowing rivers and in dams (Teugels 1986). They are widely distributed to different parts of African continent being native to streams in the Tolga oasis in Algeria. However, their cultivation in fish farms in Europe, Asia and South America have made them wide spread around the world (Vitule et al. 2006). In Nigeria, with an up surge in demand for fish, there is a huge expanding population of $C$. gariepinus which is the most cultivated catfish in the country aquaculture (De Graaf \& Janssen 1996). C. gariepinus appeared most desirable because they widely tolerate extreme environmental conditions. This paper was therefore aimed at determining the effect of sub-lethal concentrations of Aluminum phosphide on the vital organs of Clarias gariepinus juveniles.

\section{MATERIALS AND METHODS}

Experimental fish. Clarias gariepinus juveniles belonging to the same cohort $(40.1 \pm 1.2 \mathrm{~g} ; 18.1 \pm 1.1 \mathrm{~cm})$ from a commercial fish farm were transported to zoology department laboratory in plastic containers to static bath systems well aerated. They were acclimatized in laboratory condition within the temperature range of $15-22^{\circ} \mathrm{C}$ for two weeks and fed a commercial diet before the commencement of the experiment. Unconsumed feed and faeces were removed daily and water replenished regularly. The investigation was conducted in the month of November 2011.

Laboratory methods. Ten fish were randomly placed in each of 15 plastic tanks containing 15 liters of water.

Fish were exposed for 96 hrs using a static bath system to three sub-lethal concentrations (treatments) of phostoxin $\left(0.125,0.250,0.5 \mathrm{mg} \mathrm{L}^{-1}\right)$ and a phostoxin free control. The doses were determined based on probit analysis which was conducted to determine the $\mathrm{LC}_{50}$ at $96 \mathrm{hrs}$ and the value obtained was $2.75 \mathrm{mg} \mathrm{L}^{-1}$. The $20 \%$ of the $\mathrm{LC}_{50}$ value ( $2.75 \mathrm{mg} \mathrm{L}^{-1}$ ) was used as the highest test concentration. The rationale for using $20 \%$ of $\mathrm{LC}_{50}$ value of phostoxin as the highest dose was to keep within the limit of sublethal concentration. The two other doses used were a reduction in concentration of the highest dose in a graded manner. The half concentration of the highest dose $(50 \%$ reduction) was used as the second dose while the third dose was $50 \%$ reduction in concentration of the second dose. This progressive reduction of dose in a graded manner was to establish dose dependent effect on the study. Each treatment was triplicated. Crushed tablets of phostoxin were added to the water in the tanks to obtain desired treatment concentrations. Fish were observed at one hour intervals to note behavioral changes in the first $24 \mathrm{hrs}$, after which observations were made at two hour intervals. The behavior, mortality and other external changes were recorded.

Fish dissection. At the end of the exposure period (96 hrs), a fish each was randomly taken from the treatment tanks, sacrificed under chloroform anaesthesia by placing the fish in a closed glass chamber containing soaked chloroform $\left(\mathrm{CHcl}_{3}, 99-99.6 \%\right)$ in a cotton wool. They were later dissected and the gills, hepatic and renal tissues need for histopathology were removed and fixed in Bouin's fluid for 7 days. The above organs were considered for histopathological examination because in fish, the gill (respiratory organ) is the first contact to toxicant while liver is equally very susceptible to pathological changes because of its unique role in detoxification of ingested toxic materials. To a less extent, the kidney is likeable to inflammatory challenges due to the role it plays in aiding the removal of detoxified waste substances.

Slide preparation. The fixed target organs in Bouin's fluid were removed and dehydrated in increasing concen- 
trations of alcohol: 70\%, 80\%, 90\% and absolute alcohol $(100 \%)$. The organs were treated with acetone and then cleared in xylene for $30 \mathrm{~min}$ to enhance the tissue transparency, followed by impregnating and embedding in paraffin wax. Each tissue was then sectioned at $5 \mu \mathrm{m}$ and cleared (dewaxed) for staining with haematoxylin and eosin (Mbaka et al. 2014).

\section{RESULTS}

\section{Gills}

Gill morphology of the control group (Fig.1a) showed primary and secondary lamellae which was typical of other teleost fish. The lamellae were covered by squamous epithelium composed of undifferentiated pavement cells. The epithelial lining of the primary lamellar was regular showing more than two cell layers with the chloride cells visible which appeared more predominant at the base of the secondary lamellar. Deep to the epithelium were blood sinuses located in the substance of the pillar cells. Traces of vascular channels were spotted within the muscular tissue. At the lamellar core was the rigid mass of cartilaginous tissue and around it were muscle fibres. The secondary lamellar was a tender projection from the primary lamellar having delicate epithelial lining for easy gaseous exchange while the pillar cells assist with support.

Clarias gariepinus was exposed in three different concentrations of phostoxin at sub-lethal levels for $96 \mathrm{hrs}$. At the end, several pathological changes occurred which increased with concentration. The main changes observed following exposure at $0.125 \mathrm{mg} \mathrm{L}^{-1}$ (Fig. 1b) was non continuous epithelial lining especially at the more delicate respiratory secondary lamellar indicating signs of hyperplasia and epithelial lesion. There was intermittent fusion at the adjacent secondary lamellar as a result of hyperplasia. At $0.250 \mathrm{mg} \mathrm{L}^{-1}$ dose (Fig. 1c), the adjacent secondary lamellar had become almost completely fused forming a continuous lining as a result of more extensive hyperplasia of more delicate respiratory epithelium. At $0.50 \mathrm{mg} \mathrm{L}^{-1}$ (Fig.1d), the secondary lamellae exhibited marked necrotic changes with complete disintegration of the lamellae characterized by accentuated epithelia lifting and detachment. There was intense vasodilatation and many vacuoles. The pillar cells had been altered and blood spaces expanded as a result of the supervening distress.

\section{Liver}

A section of hepatic tissue of the control group showed
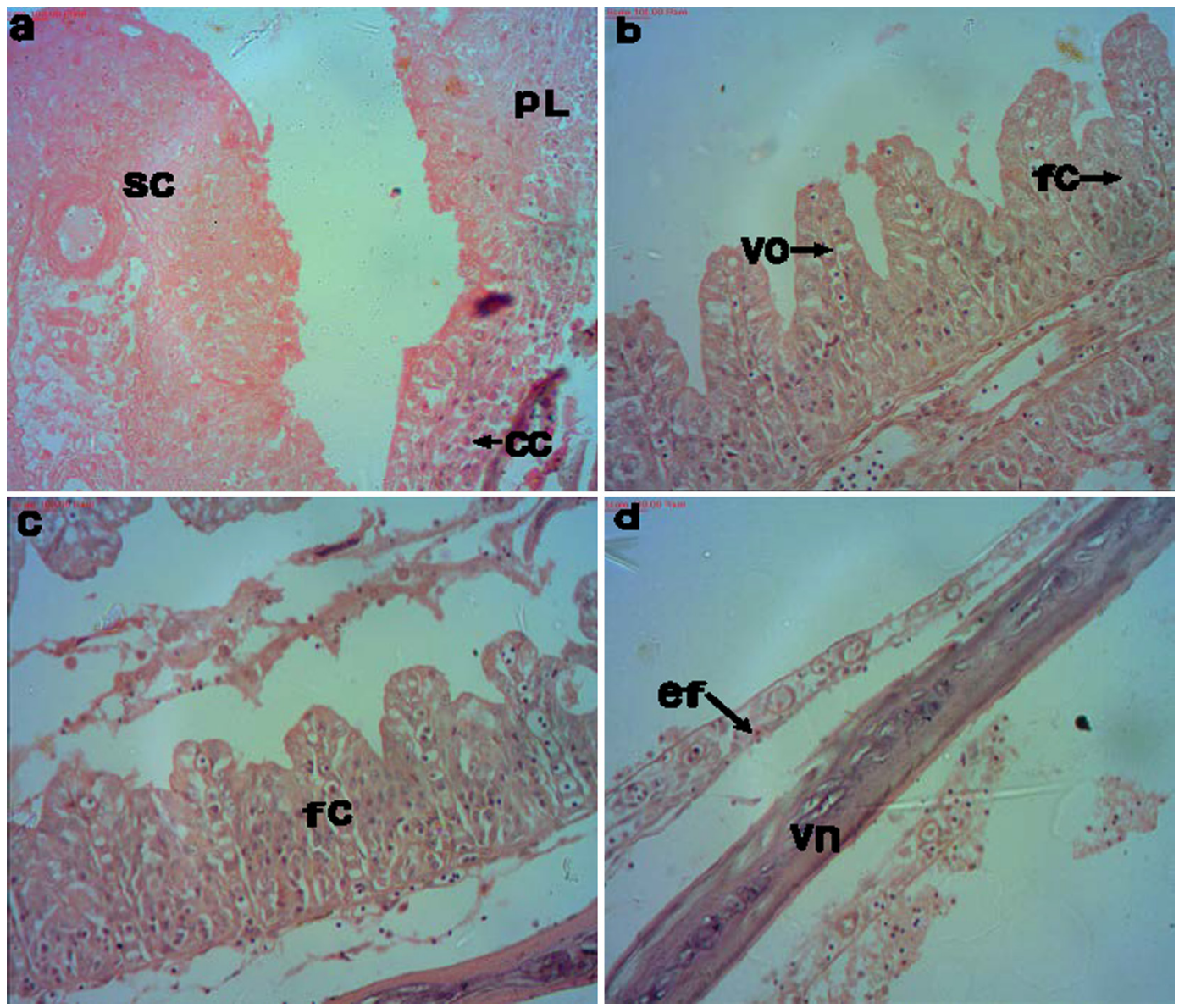

Fig.1. (a-d) Photomicrograph showing transverse section of gill filaments of Clarias gariepinus juveniles. (a) Control showing normal appearance of gill filaments, primary lamellae (pL), secondary lamellae (sc), chloride cell (cc) and polar cell (pc). (b) Gill of exposed at $0.125 \mathrm{mg} \mathrm{L}^{-1}$ indicating mild hyperplasia with fused (fc) and un-fused secondary lamellar (vo). (c) Gill of exposed at $0.250 \mathrm{mg} \mathrm{L}^{-1}$ indicating severe hyperplasia with complete fusion of secondary lamellae (fc). (d) Gill of exposed at 0 . mg L $\mathrm{L}^{-1}$ showing complete disintegration of secondary lamellae, epithelial lifting (ef) exposing central venous sinus (vn). Obj.40x. 
normal architecture (Fig.2a). It exhibited typical parenchymal appearance though with indistinct hepatic lobules. The polygonal shaped hepatocytes were arranged as irregular cord-like structure separated by sinusoids. Each cord extended from the peri-lobular margin and showed normal convergence to the central vein. The hepatic tissue after exposure at the dose of $0.125 \mathrm{mg} \mathrm{L}^{-1}$ (Fig.2b) showed no apparent inflammation within the hepatic parenchyma. The hepatic sinusoids were however ill defined. At the dose of $0.250 \mathrm{mg} \mathrm{L}^{-1}$ (Fig.2c) there was mild inflammatory changes indicating diffuse presence of lymphocytic cells. There was also an onset of edematous changes and vacuolation. At the dose of $0.5 \mathrm{mg} \mathrm{L}^{-1}$ (Fig.2d), inflammatory changes had become more apparent indicating more profound edematous changes with the hepatic parenchyma shown to be eroded with infiltrating leukocytes. Also observed in the parenchyma were hydropic degeneration and pyknotic changes of the hepatocytes.

\section{Kidney}

The histology of the control group showed (Fig.3a) normal architecture of the renal cortical tissue. The renal corpuscles appeared as rounded structure surrounded by narrow space, the Bowman's space. The cortical tubules seen in this section consisted mainly of proximal convoluted tubules with few of the distal convoluted tubules indica- ted. After exposure at the dose of $0.125 \mathrm{mg} \mathrm{L}^{-1}$ (Fig.3b) and $0.250 \mathrm{mg} \mathrm{L}^{-1}$ (Fig.3c) respectively no noticeable distortion was observed. But at $0.5 \mathrm{mg} \mathrm{L}^{-1}$ (Fig.3d) dose, mild inflammatory change occurred at the interstices. The convoluted tubules exhibited partial shrinkage with a coalesced space around.

\section{DISCUSSION}

Fishes are prone to various toxic challenges as these substances are freely disposed into the streams and rivers not considering their deleterious effect on aquatic life. (Jiraungkoorskul et al. 2002). Fish species are most sensitive to aquatic pollutants during their early life stages. It has been reported that when water quality is affected by toxicants, physiological changes occur which are reflected in behavioral changes and swimming activity of fish (Heath 1991, Adeyemo et al. 2004). In this study, severe abnormal behavior was observed such as incessant jumping and gulping of air, restlessness, loss of equilibrium, increase in opercular activity, sudden quick movement and occasional motionlessness at the bottom of the bath. This finding was in agreement with similar behavior observed in Clarias gariepinus exposed to certain pesticides (Omoniyi et al. 2002, Rahman et al. 2002). The stressful and erratic behavior of C. gariepinus indicated respiratory distress believed to have been caused by the undesirable effect of phostoxin on the gills.
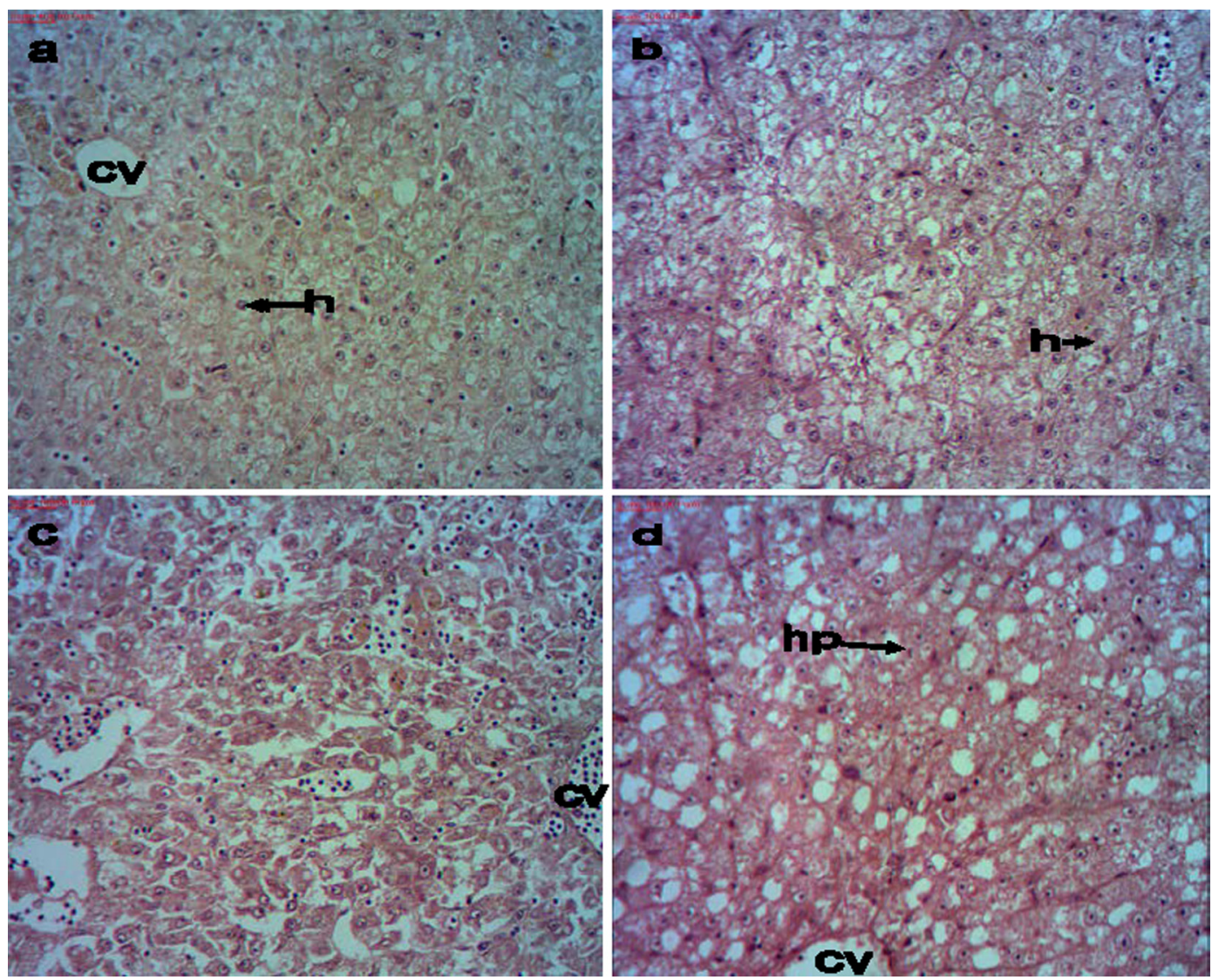

Fig.2. (a-d) Photomicrograph showing transverse section of hepatic tissue of Clarias gariepinus juveniles. (a) Control showing normal parenchyma indicating hepatocytes (h) and central vein (cv). (b) Exposure at $0.125 \mathrm{mg} \mathrm{L}^{-1}$ showing normal hepatocytes (h). (c) Hepatic tissue exposure at $0.250 \mathrm{mg} \mathrm{L}^{-1}$ indicating slight leukocytes infiltration. (d) Exposure at $0.5 \mathrm{mg} \mathrm{L}^{-1}$ indicating severe inflammatory changes with hydropic degeneration (hp). Obj.40x. 

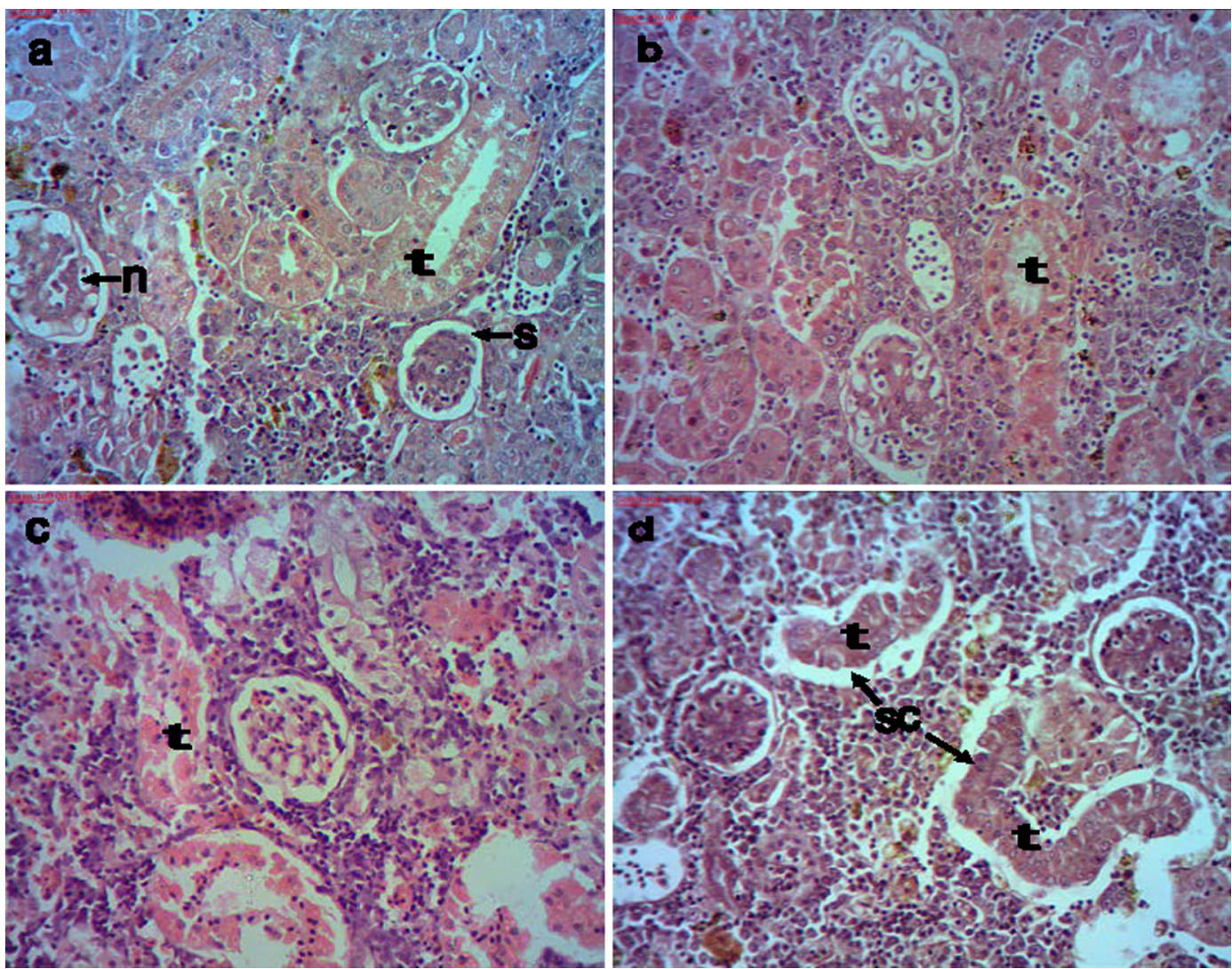

Fig.3. (a-d) Photomicrograph of transverse section of the renal tissue of Clarias gariepinus juveniles. (a) Control showing renal corpuscles (n), the Bowman's space (s) and the convoluted tubules (t). (b) Exposure at $0.125 \mathrm{mg} \mathrm{L}^{-1}$ showing convoluted tubules (t). (c) Exposure at $0.250 \mathrm{mg} \mathrm{L}^{-1}$ indicating convoluted tubules $(\mathrm{t})$. (d) Exposure at $0.5 \mathrm{mg} \mathrm{L}^{-1}$ showing mild inflammatory changes at the interstices with the convoluted tubules showing partial shrinkage surrounded by coalesced spaces (sc). Obj.40x.

Histopathological changes have been widely used as biomarkers in evaluating the health of fish exposed to contaminants, both in the laboratory (Thophon et al. 2003) and in the field studies (Hinton et al. 1992, Teh et al. 1997). Juveniles of C. gariepinus of same cohort showed progressive pathological changes in their vital organs such as the gills and liver when stressed at three different sub-lethal concentrations of phostoxin. At the lowest dose of exposure, the gills showed mild hyperplasia with intermittent fusion at the secondary lamellar indicating inflammatory changes. There was also an indication of increased mucus secretion which has been reported in phosphine gas toxicity to fish (Ayoola \& Ajani 2007). When the dose was doubled $\left(0.250 \mathrm{mgL}^{-1}\right)$, there was severe hyperplasia with nearly complete fusion of secondary lamellar. Lamellar fusion is seen as normal occurrence when fishes are exposed to toxic agents in water (Nowak 1992, Olurin et al. 2006). The reaction could be explained as adaptogenic which may be to minimize surface area contact to toxic agent or body changes in response to irritant substance. The increase in thickness of epithelial layers and fusion of adjacent secondary lamellae would not only decrease the surface area available for oxygen extraction but would also increase the oxygen diffusion distance between water and blood (Skidmore \& Tovell 1972). Although this may have served as a protective effect against the noxious agent, it is however an impediment to respiratory process. At the highest dose of sub-lethal concentration of phostoxin exposure, there was complete disintegration of secondary lamellae, increased vacuolation, accentuated lamellae epithelia lifting and epithelia detachment as well as tissue hypoxia and arterial rupture due to the supervening respiratory distress. According to an earlier report, phosphine gas on exposure to fish causes an accelerated lipid peroxidation known to cause membrane damage (Wahab et al. 2008).

In toxic environments, the hepatic tissue is usually a prime target because of its unique role in detoxification process. Fish liver, however, has been reported not to show the diversity of pathological changes seen in higher animals on the account of lack of kuppfer cells in the hepatic sinusoids (Ellis et al. 1976). Nevertheless, its susceptibility to a number of toxic and consequential metabolic disturbances has been highlighted (Jiraungkoorskul et al. 2003, Olojo et al. 2005, Mobarak \& Sharaf 2011). At the lowest dose of the sub-lethal concentration, there were no traces of inflammatory changes although the sinusoids were ill defined. At increased concentration $\left(0.250 \mathrm{mg} \mathrm{L}^{-1}\right)$ there were signs of leukocytes infiltration and increased vacuolation which were manifestation of inflammatory changes. Inflammatory response is seen as the basic protective response to tissue damage and it may be considered as the product of series of changes that takes place following injury. At the highest concentration $\left(0.5 \mathrm{mg} \mathrm{L}^{-1}\right)$ of exposure, more severe inflammatory changes occurred that include hydropic de- 
generation and pyknotic changes of hepatocytes. The hepatocytes appeared disarranged while the hepatic sinusoids were no longer outlined. It has been established that fish exposed to toxicants exhibit increase in hepatic vacuolization (Coimbra et al. 2007, Fiuza et al. 2009, Mobarak \& Sharaf, 2011). The increase in vacuolation could have been as a result of imbalance between the rate of synthesis of substances and the rate of release to systemic circulation (Ginerich 1982, Jiraungkoorskul et al. 2002). Pyknosis and karyolysis have been reported in cases of severe poisoning.

The glomerular complex is vital to renal filtration and therefore its lesion would lead to impaired renal function. In this case, no lesion was observed in the kidney after exposure to phostoxin at $0.125 \mathrm{mg} \mathrm{L}^{-1}$ and $0.250 \mathrm{mg} \mathrm{L}^{-1}$ dosages respectively while mild inflammatory changes occurred in the interstices at the highest dose of exposure particularly with the shrinkage of convoluted tubules. The sub-lethal concentration of phostoxin used and the duration of exposure may have accounted for less effect of the toxicant on the kidney. It could also be viewed in the context that the organ was not the first contact to the toxicant. More often ingested toxic substances are detoxified in the liver and before it can reach potentially toxic level to have affected other internal organs like the kidney, it would have caused extensive damage to the liver. Damage to kidney has been observed following fish exposure to toxicants (Jiraungkoorskul et al. 2003).

\section{CONCLUSIONS}

The sub-lethal concentrations of phostoxin exhibited wide spectrum of histopathological changes on Clarias gariepinus in which significant alterations occurred in the tissue morphology and in the cyto-architecture of the gills and to a considerable extent liver and kidney of the exposed fingerlings.

In the light of the fact that marked deleterious effect occurred at the sub-lethal doses, phostoxin should therefore be used with serious precaution.

Conflict of interest statement.- The authors hereby declare that there is no conflict of interest in the study.

\section{REFERENCES}

Adeyemo O.K., Akintoye O.A. \& Oghi M.L. 2004. Acute toxicity of chlorpyrifos (Dursban<sup $>$ andreg; $<$ /sup $>$ ) to $<$ I $>$ Clarias gariepinus $<$ /I $>$ juveniles. Trop. Vet. 22:7-11.

Atta A.Y., Abubakar M.B. \& Adefila S.S. 2009. Production of alum from spent phostoxin. J. Applied Sci. Res. 5(10):1812-1815.

Ayoola S.O \& Ajani E.K. 2007. Histopathological Effects of cypermethrin on Juvenile Nile Tilapia (Oreochromis niloticus). Afri. J. Livestock Extension 6:1-13.

Chugh S.N. 1992. Aluminium phosphide poisoning: Present status and management. J. Assoc. Physicians India 40:401-405.

Coimbra A.M., Figueiredo-Fernandes A. \& Reis-Henriques M.A. 2007. Nile tilapia (Oreochromis niloticus), liver morphology, CYP1A activity and thyroid hormones after endosulfan dietary exposure. Pestic. Biochem. Physiol. 89:230-236.

Degesch America, Inc. 1988. Material Safety Data Sheet: Aluminum Phosphide, Phostoxin, Degesch America, Weyers Cave, VA.

De Graaf G.J. \& Janssen H. 1996. Artificial reproduction and pond rearing of the African catfish Clarias gariepinus in Sub-Saharan Africa: a handbook. FAO Fisheries Technical Paper no. 362. FAO, Rome. 73p.

Das P.C., Ayyapan S., Jena J.K. \& Das B.K. 2004a. Acute toxicity of ammonia and its sublethal effects on selected haematological and enzymatic parameter of mrigal, Cirrhinus mrigata (Hamilton). Aquaculture Res. 35:134-143. (Medline)

Das P.C., Ayyappan S., Jena J.K. \& Das B.K. 2004b. Effect of sub-lethal nitrite on selected haematological parameters in fingerling Catla catla (Hamilton). Aquaculture Res. 35:874-880. (Medline)

Gordon K. 1972. Training Manual for the Structural Pesticide Applicator. Rosemead, California, p.123-140.

Ellis A.E., Munro A.L.S. \& Roborts R.J. 1976. Defence mechanisms in fish. 1. A study of the phagocytic system and the fate of intraperitoneally injected particulate material in the plaice $(<\mathrm{I}>$ Pleuronectes platessa $</ \mathrm{I}>\mathrm{L}$. $)$. J. Fish. Biol. 8:67-78. (Medline)

Fiuza T.S., Silva C.P., De Paula J.R., Tresvenzol L.M.F. \& Saboia-Morais S.M.T. 2009. The effect of crude ethanol extract and fractions of Hyptidendron canum (Pohl ex Benth.) Harley on the hepatopancreas of Oreochromis niloticus L. Biol. Res. 42:153-162. (Medline)

Ginerich W.H. 1982. Hepatic Toxicity of Fishes, p.55-105. In: Weber L.J. (Ed.), Aquatic Toxicology. Raven Press, New York.

Jiraungkoorskul W., Upatham E.S., Kruatrachue M., Sahaphong S., Vichasri-Grams S. \& Pokethitiyook P. 2002. Histopathological effects of roundup, a glyphosate herbicide, on Nile tilapia (Oreochromis niloticus). Science Asia 28:121-127.

Jiraungkoorskul W., Upatham E.S., Kruatrachue M., Sahaphong S., Vichasri-Grams S. \& Pokethitiyook P. 2003. Biochemical and histopathological effects of glyphosate herbicides on Nile tilapia (Oreochromis niloticus). Environ. Toxicol. 18(4):260-268. (Medline)

Heath A.G. 1991. Water Pollution and Fish Physiology. 2nd ed. Lewis Publ., Boca Raton. 359p.

Hinton D.E., Baumann P.C., Gardner G.R., Hawkins W.E., Hendricks J.D., Murchelano R.A. \& Okihiro M.S. 1992. Histopathologic biomarkers, p.155-195. In: Hugget R., Kimerle R., Merles P. \& Bergman H. (Eds), Biomarkers Biochemical, Physiological and Histological Markers of Anthropogenic Stress. Lewis Publ., BocaRaton.

Huertas M., Gisbert E., Rodriguez A., Cardona L., Williot P. \& Castello-Orvay E. 2002. Acute exposure of Siberian sturgeon $(<\mathrm{I}>$ Acipenser baeri $</ \mathrm{I}>$, Brandt) yearlings to nitrite: median-lethal concentration ( $\mathrm{LC}<\mathrm{sub}>50<$ ) sub>) determination, haematological changes and nitrite accumulation in selected tissues. Aquat. Toxicol. 57:257-266. (Medline)

Kori-Siakpere O., Ikomi R.B. \& Ogbe M.G. 2011. Biochemical response of the African catfish: $<$ I $>$ Clarias gariepinus $</$ I $>$ (Burchell, 1822) to sublethal concentrations of potassium permanganate. Ann. Biol. Res. 2:1-10.

Leuschner F. 1984. Evaluation of the acute toxicity of Phostoxin (active ingredient: aluminum phosphide) to rainbow trout. Laboratory for Pharmacology and Toxicology, Hamburg, German Federal Republic.

Martinez C.B.R. \& Souza M.M. 2002. Acute effects of nitrite on ion regulation in two neotropical fish species. Comp. Biochem. Physiol. A 133:151160.

Mbaka G.O., Ogbonnia S.O. \& Awoyemi F.0. 2014. Acute and sub-acute toxicity studies of ethanol seed extract of Raphia hookeri on Swiss albino rats. Brit. J. Pharm. Res. 4:1196-1208.

Mobarak Y.M.S. \& Sharaf M.M. 2011. Lead acetate-induced histopathological changes in the gills and digestive system of silver sailfin molly (Poecilia latipinna). Int. J. Zool. Res. 7:1-18.

Nath N.S., Bhattacharya I., Tuck A.G., Schlipalius D.I. \& Ebert P.R. 2011. Mechanisms of phosphine Toxicity. J. Toxicol. DOI: 10.1155/2011/494168. (Medline)

Nowak B. 1992. Histological changes in gills induced by residues of endosulfan. Aquat. Toxicol. 23:65-83. [Medline]

Ofuya T.I., Olotuah O.F. \& Akiyoade D.O. 2010. The effect of storage on the efficacy of Eugenia aromatic (Baill.) in the control of Callosobruchus maculates (Fabricius) (Coleoptera; Bruchidae) Pest. J. Appl. Sci. Environ. Manage. 14:97-100. 
Olojo E.A.A., Olurin K.B., Mbaka G. \& Oluwemimo A.D. 2005. Histopathology of the gill and liver tissues of the African Catfish gariepinus Clarias exposed to lead. Afri. J. Biotech. 4(1):117-122.

Olurin K.B., Olojo E.A.A., Mbaka G.O. \& Akindele A.T. 2006. Histopathological responses of the gill and liver tissues of $<$ I $>$ Clarias gariepinus $<$ / I $>$ fingerlings to the herbicide, glyphosate. Afr. J. Biotech. 5:2480-2487.

Omoniyi I.A., Agbon A.O. \& Sodunke S.A. 2002. Effect of lethal and sub-lethal concentrations of tobacco $(<\mathrm{I}>$ Nicotiana tobaccum $</$ I $>)$ leaf dust extract on weight and hematological changes in $<$ I $>$ Clarias gariepinus $<$ | I> (Burchell). Pest. J. Applied Sci. Environ. Manage. 6:37-41.

Rabitto I.S., Alves Costa J.R., Silva de Assis H.C., Pelletier E.E., Akaishi F.M., Anjos A., Randi M.A. \& Oliveira Ribeiro C.A. 2005. Effects of dietary Pb (II) and tributyltin on neotropical fish, Hoplias malabaricus: Histopathological and biochemical findings. Ecotoxicol. Environ. Safety. 60:147156. [Medline]

Rahman M.Z., Hossain Z., Mellah M.F.R. \& Ahmed G.U. 2002. Effect of diazinon 60EC on Anbus testudineus, channa punctatus and Barbades gomonotus Naga. The ICLARM Quart. 25:8-11. [Medline]

Shuhaimi-Othman M., Nadzifah Y., Nur-Amalina R. \& Umirah N.S. 2012. Deriving freshwater quality criteria for iron, lead, nickel, and zinc for protection of aquatic life in Malaysia. Sci World J. doi: 10.1100/2012/861576.

Skidmore J.F. \& Tovell P.W.A. 1972. Toxic effects of zinc sulphate on the gills of rainbow trout. Waters Res. 6:217-230. (Medline)
Stentiford G.D., Longshaw M., Lyons B.P., Jones G., Green M. \& Feist S.W. 2003. Histopathological biomarkers in estuarine fish species for the assessment of biological effects of contaminants. Mas. Environ. Res. 55:137-159. (Medline)

Teh S.J., Adams S.M. \& Hinton D.E. 1997. Histopathological biomarkers in feral freshwater fish populations exposed to different types of contaminant stress. Aquatic Toxicol. 37:51-70. (Medline)

Teugels G.G. 1986. A systematic revision of the African species of the genus Clarias (Pisces; Clariidae). Ann. Mus. R. Afr. Centr., Sci. Zool. 247:199.

Thophon S., Kruatrachue M., Upathan E.S., Pokethitiyook P., Sahaphong S. \& Jarikhuan S. 2003. Histopathological alterations of white sea bass, $L a-$ tes calcarifer in acute and sub-chronic cadmium exposure. Eviron. Pollution 121:307-321. (Medline)

Wahab A., Zaheer M.S., Wahab S. \& Khan R.A. 2008. Acute aluminium phosphide poisoning: an update. Hong Kong J. Emerg. Med. 15:152-155. (Medline)

Varo I., Nunes B., Atmat F., Torrenblaca A., Guilhermino L. \& Navarro J.C. 2007. Effect of sublethal concentrations of copper sulphate on seabream $<$ I $>$ Sparus aurata</I $>$ fingerlings. Aquat. Living Resour. 20:263-270. (Medline)

Vitule J.R.S., Umbria S.C. \& Aranha J.M.R. 2006. Introduction of the African catfish Clarias gariepinus (Buchell, 1822) into Southern Brazil. Bio. Invasions 8:677-681. DOI 10.1007/s10530-005-2535-8. (Medline) 